Nilai-nilai persatuan dan kesatuan dalam keberagaman suku bangsa

\title{
NILAI-NILAI PERSATUAN DAN KESATUAN DALAM KEBERAGAMAN SUKU BANGSA
}

\author{
Putri Ayu Venty El Hanief \\ Institut Ilmu Kesehatan STRADA Indonesia \\ ventyhanief@gmail.com
}

\begin{abstract}
Abstrak
Berdirinya organisasi-organisasi pemuda yang bersifat kedaerahan memperlihatkan adanya kesadaran untuk bersatu, walaupun masih bersifat terbatas pada daerah masing-masing. Pada dasawarsa ke-2 abad 20, rasa kedaerahan mulai memudar digantikan oleh keinginan untuk membentuk persatuan yang bersifat nasional. Sebagai puncak keinginan keinginan pemuda untuk membentuk persatuan yang bersifat nasional yaitu Sumpah Pemuda 28 Oktober 1928.

Sumpah Pemuda yang diputuskan dalam Kongres Pemuda II, 28 Oktober 1928, mempunyai arti yang penting dalam perkembangan bangsa Indonesia. Semangat persatuan yang dikumandangkan bersama berhasil mengatasi prasangka suku, golongan, dan budaya. Sumpah Pemuda menjiwai perjuangan nasional selanjutnya dan kehidupan bangsa indonesia sesudah mencapai kemerdekaan.

Nilai-nilai budaya tentang persatuan dan kesatuan sebenarnya telah dimiliki dan dijunjung tinggi oleh masing-masing suku bangsa di Indonesia. Nilai-nilai tersebut antara lain: 1) Nilai yang terkait pada ajaran dasa mawa cara negara mawa tata; 2) Nilai yang terkait pada ajaran kiwa tengen mula matunggalan; 3) Nilai toleransi; 4) Nilai menjunjung tinggi masyarakat dan kegotongroyongan; 5) Nilai kesetiakawanan dan 6) Nilai tenggang rasa. Apabila nilai-nilai tersebut betul-betul bisa dilaksanakan maka kedamaian dan ketentraman akan terwujud di Indonesia. 'Bhineka Tunggal Ika' bukan hanya sebagai semboyan saja, tetapi merupakan pengikut negara Republik Indonesia yang terdiri dari beribu-ribu pulau besar dan kecil serta dihuni beratus-ratus suku bangsa.
\end{abstract}

Kata Kunci : Suku, Persatuan, Kesatua 


\section{Latar Belakang}

Kutipan Putusan Kongres Pemuda Pemudi Indonesia pada tanggal 28 Oktober 1928 tersebut di atas, pada hakekatnya merupakan pernyataan integrasi bangsa yang dilakukan oleh berbagai organisasi pemuda pada masa lalu. Adapun organisasi pemuda tersebut yakni Jong Jva, Jong Sumatranen Bond (Pemuda Sumatra), pemuda Indonesia Sekar Rukun Jong Islamienten Bond (Pemuda Islam), Jong Celebes, Jong Batak, Pemuda Betawi, dan Perhimpunan Pelajar-Pelajar Indonesia.

Keputusan Kongres Pemuda Tahun 1928 tersebut merupakan tonggak sejarah yang sangat penting dan telah mengajarklan pada kita, bahwa mendahulukan kesukuan dan kedaerahan dari pada kepentingan nasional dan persatuan adalah suatu tindakan yang sia-sia. Terbukti bahwa dalam berbagai perjuangan yang dilakukan oleh bangsa kita secara kedaerahan tanpa persatuan senantiasa gagal dan mendatangakan kesengsaraan. Sehingga kita dijajah oleh bangsa Belanda, Portugal, Inggris dan bangsa Jepang, Sungguh suatu penderitaan yang sangat pahit dan menyedihkan.

Oleh karena itu 'ikrar' atau 'Sumpah Pemuda' yang diputuskan dalam Kongres Pemuda, 28 Oktober 1928 oleh organisasi-organisasi pemuda adalah sangat tepat dan strategis dalam memperkokoh persatuan dan kesatuan untuk melawan penjajah. Akhirnya dengan mengkristalnya persatuan dan kesatuan bangsa, kemerdekaan dapat direbut dari penjajah jepang dan berkumandanglah Proklamasi Kemerdekaan pada tanggal 17 Agustus 1945 yang diproklamasikan oleh Soekarno - Hatta.

Sementara itu dalam rangka memelihara persatuan dan kesatuan bangsa pembukaan Undang Undang Dasar 1945 telah menegaskan bahwa melindungi segenap bangsa Indonesia dan seluruh tumpah darah Indonesia dengan berdasar atas persatuan dengan mewujudkan keadilan sosial bagi seluruh rakyat Indonesia. Pernyataan tersebut menegaskan bahwa negara telah menghindari segala paham golongan menghindari segala paham perseorangan yang dapat memecah belah negara. Prinsip persatuan adalah diatas segalanya. Kondisi ini adalah merupakan suatu nilai dasar yang telah disepakati oleh bangsa Indonesia sejak dari awal. Kebangsaan yang kita bangun tidak tegak diatas landasan dan kepentingan suku bangsa, agama, ras, dan ikatan-ikatan primordial, melainkan persatuan nasional itu kita bangun dan tegakkan justru di atas landasan suku 
bangsa berangkat dari kesadaran untuk memperbaiki nasib sebagai satu bangsa.

Selanjutnya kedudukan Warga Negara Indonesia telah diatur sesuai hak dan kewajiban yang tercantum dalam pasal-pasal UUD 1945 seperti Pasal 27, Ayat 1 yang berbunyi: 'Segala warga negara bersamaan kedudukannya didalam hukum dan pemerintah dengan tidak ada kecualinya' Di samping itu warga negara dalam mendapat pekerjaan telah dijelaskan dengan tegas tanpa membedakan dari golongan mana, seperti tercakup dalam pasal 27 Ayat 2 yang berbunyi: 'Tiap warga negara berhak atas pekerjaan dan penghidupan yang layak'. Sedang hak memeluk agama sesuai Keyakinan tercakup dalam pasal 29, Ayat 2, dan hak memperoleh pendidikan tercakup dalam Pasal 31, Ayat 2.

Dari keyakinan tersebut, jelaslah bahwa negara sama sekali tidak membedakan antara satu warga dengan warga lainnya. Semua warga negara mempunyai tanggung jawab terhadap kewajiban, yaitu untuk mempertahankan negara seperti tercantum pada UUD 1945 Pasal 30, Ayat 1. Pembelaan di sini bukan berarti dalam pengertian sempit hanya semata-mata terhadap serangan musuh, tetapi dalam peengertian yang lebih luas yaitu memelihara negara dengan menjaga keserasian dan keselarasan hidup di masyarakat dengan aneka ragam suku bangsa, agama, ras dan budaya.

\section{Kasus/Masalah}

Indonesia adalah sebuah negara yang memiliki letak strategis karena berada di antara dua benua, yakni Asia dan Ausralia, dan dua samudera yakni Samudera Hindia (Indonesia) dan Samudra Pasifik. Kondisi letak demikian sangat menguntungkan di samping juga banyak menyimpan potensi yang dapat dieksploitir untuk mengancam persatuan dan kesatuan. Potensi itu antara lain adalah faktor geografi, heteroginitas suku bangsa, agama dan kultur, kesenjangan ekonomi dan sosial yang relatif lebar serta pertikaian politik ideologis.

Potensi geografis yang kaya raya, terdiri atas ribuan pulau-pulau besar dan kecil (16.000 pulau) yang membujur dari barat ke timur; dan Sabang sampai Merauke dengan kekayaan alamnya yang melimpah, indah dan subur. Jumlah Sukubangsa di Indonesia adalah $485^{4}$ dan berdasarkan propinsi, tercatat: 1 . Propinsi Bali 4 sukubangsa; 2. Propinsi Bengkulu 9 sukubangsa; 3. Propinsi D.I. Aceh 11 sukubangsa; 4. Propinsi D.I. Yogyakarta 1 sukubangsa; 5. Propinsi Daerah Khusus Ibukota Jakarta 1 sukubangsa; 6 Propinsi Irian Jaya 116 sukubangsa; 7. Propinsi Jambi 6 
sukubangsa; 8. Propinsi Jawa Barat $5^{6}$ sukubangsa; 9. Propinsi Jawa Tengah 5 sukubangsa; 10. Propinsi Jawa Timur 6 sukubangsa; 11. Propinsi Kalimantan Barat 71 sukubangsa; 12.Propinsi Kalimantan Selatan 10 sukubangsa; 13. Propinsi Kalimantan Tengah 10 sukubangsa; 14. Propinsi Kalimantan Timur 29 sukubangsa; 15. Propinsi Lampung 10 sukubangsa; 16. Propinsi Nusa Tenggara Barat 9 sukubangsa; 17. Propinsi Maluku 73 sukubangsa; 18. Propinsi Nusa Tenggara Timur 46 sukubangsa; 19. Propinsi Riau ${ }^{8} 9$ sukubangsa; 20. Propinsi Sulawesi Selatan 13 sukubangsa; 21. Propinsi Sulawesi Tengah 13 sukubangsa; 22. Propinsi Sulawesi Utara 920 sukubangsa; 23. Propinsi Sumatera Barat 2 sukubangsa; 24. Propinsi Sumatera Selatan 29 suku angsa; 25. Propinsi Sumatera Utara 4 sukubangsa. Sedang Propinsi Sulawesi Tenggara tidak/belum terdata. Masing- masing sukubangsa tersebut memiliki adat istiadat dan budaya, serta cara hidup yang berbeda. Dengan adat istiadat dan budaya tersebut mereka hidup dengan ciri khasnya masing-masing. Mereka menata hidup untuk beradaptasi dengan lingkungannya.

Berbagai ragam seni muncul sesuai dengan ciri khas lingkungan masingmasing yang memberikan warna kehidupan masyarakat Indonesia. Belum lagi adanya perbedaan agama dan kepercayaan yang dianut oleh masingmasing sukubangsa menambah beragamnya kehidupan di Indonesia. Adanya tingkat perkembangan masingmasing suku yang berbeda, menyebabkan ada sukubangsa yang telah berada di kota-kota besar dan kota metropolitan. Hal ini merupakan sebuah kenyataan akan beragamnya kehidupan sukubangsa negara kita Indonesia. Penggambaran ini kemudian tercermin dalam semboyan bangsa Indonesia yakni 'Bhineka Tunggal Ika'. Semboyan ini adalah sangat tepat dan merupakan tali pengikat agar masing-masing warga atau sukubangsa atau golongan tidak melihat dari sudut pandang sukubangsanya, golongannya ataupun daerahnya sendiri, akan tetapi hendaknya mampu melihat dengan pandangan yang lebihluas, yaitu lingkungan nasional atau bangsa sehingga persatuan dan kesatuan bangsa terus tercipta.

\section{Tinjauan pustaka}

Kebhinekaan yang ada di Indonesia tidak hanya yang menyangkut masyarakat- nya. Namun dari segi daerah pun terdapat suatu perbedaan yang sangat berarti yakni antara kondisi daerah Indonesia bagian timurdan bagian barat. Untuk Indonesia bagian timur tanahnya berawa dan kurang subur. 
Sedangkan untuk Indonesia bagian barat keadaan tanahnya relatif subur dengan tanah humus yang tebal. Hal ini mengharuskan persatuan dan kesatuan bangsa tetap terus menerus dibina agar dapat saling mengisi sehingga pemerataan hasil pembangunan di Indonesia dapat diwujudkan. Dengan latar belakang tersebut, maka memancing timbulnya berbagai kerawanan dan permasalahan yang dapat menghambat persatuan dan kesatuan bangsa. Oleh karena itu dalam naskah ini akan disajikan berbagai contoh permasalahan yang sering menghambat integrasi nasional yang disebabkan ketertutupan sukubangsa baik lokasi, politik maupun kurangnya pergaulanantar sukubangsa:

1. Adanya perbedaan persepsi yang disebabkan perbedaan suku bangsa. Dalam pergaulan antar sukubangsa di Indonesia, kita masih sering memakai sudut pandang stereotipe sukubangsa yang sebenarnya merupakan produk penjajah, guna memecah belah bangsa kita. Penilaian subyektif antara warga satu sukubangsa terhadap sukubangsa yang lain, misalnya orang Batak kasar, orang Madura suka berkelahi, orang Jawa itu lamban, ternyata masih sering mengemuka dalam pergaulan antar suku bangsa. Sehingga berbagai pemikiran subyektif tersebut akan sangat menghambat persatuan, kesatuan dan integrasi bangsa.

2. Perbedaan persepsi yang disebabkan perbedaan ekonomi. Perbedaan ini biasanya akan sangat tajam antara sukubangsa asli dan golongan suku bangsa keturunan seperti Cina, Arab dan lain-lain. Pada umumnya golongan sukubangsa keturunan terutama sukubangsa Cina yang tinggal di kotakota besar adalah orang-orang yang sukses dalam dunia bisnis. Kesuksesan tersebut menyebabkan timbulnya suatu kesenjangan yang tajam dengan penduduk asli. Lebih menyakitkan apabila warga sukubangsa Cina atau suku bangsa keturunan yang sukses dalam ekonomi sangat egois, sombong dan tidak mampu beradaptasi dengan lingkungannya. Akibatnya akan terjadi kecemburuan sosial, perbuatan anarki dan sebagainya terhadap suku bangsa keturunan.

3. Perbedaan persepsi yang disebabkan perbedaan agama. Indonesia secara resmi mengakui keberadaan dan kehidupan agamaagama resmi, dan hak kemerdekaan memeluk agama sesuai keyakinannya telah diatur dalam Undang Undang Dasar 1945 Pasal 29, Ayat 2. Namun bagi masyarakat majemuk seperti Indonesia hubungan antar umat 
beragama sering menyulut timbulnya konflik. Timbulnya istilah seperti Kristenisasi dan Islamisasi, misalnya mewujudkan adanya kecurigaan antara umat beragama. Akibatnya hubungan antar umat beragama cenderung tidak harmonis bahkan kadang-kadang dapat terjadi tindakan-tindakan kriminal yang bertentangan dengan hukum dan Pancasila, seperti pengrusakan rumah ibadah agama lain, peculikan atau pembunuhan terhadap penganut agama lain, perbuatan anarkisme, dan isu-isu yang mendiskreditkan penganut agama lain dan seterusnya.

4. Adanya perbedaan persepsi yang disebabkan letak geografis. Wilayah Indonesia yang terdiri dari beribu-ribu pulau dengan kekayaannya yang melimpah ruah dari Sabang sampai Merauke, dalam kenyataannya sering terjadi konflik. Hal ini disebabkan kesuburan tanah antara daerah satu dengan lainnya berbeda, seperti tanah di Indonesia bagian timur keadaannya relatif tidak subur, dan bahkan ada yang berawa-rawa, misalnya di Irian Jaya (sekarang Papua). Sedangkan keadaan tanah di Indonesia bagian barat mempunyai potensi yang lebih baik dan subur. Keadaan yang demikian itu akan menimbulkan kesulitan dalam pembangunan. Sehingga pembangunan di
Indonesia bagian barat akan relatif mudah dan lebih murah, sedangkan di Indonesia bagian timur relatif lebih sulit dan lebih mahal. Akibatnya pembangunan di Indonesia bagian timur belum dapat dilaksanakan secara maksimal. Kenyataan yang demikian ini telah menimbulkan kesenjangan di antara penduduk di dua daerah tersebut. Kesenjangan ini makin bertambah tajam dengan adanya anggapan dan persepsi yang salah seperti pembangunan hanya diprioritaskan di Jawa. Keadaan ini akhirnya akan dapat menghambat persatuan dan kesatuan bangsa serta pelaksanaan integrasi nasional.

Segala permasalahan yang terkait dengan kebhinekaan atau keragaman suku bangsa tersebut di samping mempunyai potensi-poteni yang negatif, juga mengandung potensi-potensi yang positif. Oleh karena itu masingmasing sukubangsa yang merupakan bagian dari masyarakat Indonesia akan berusaha menyadari dan memahami latar belakang timbulnya konflik-konflik tersebut. Selanjutnya kita tidak boleh terlena dalam masalah-masalah yang dapat mengganggu persatuan dan kesatuan bangsa. Untuk itu perlu kita perhatikan dan kita lihat berbagai hal yang dapat mewujudkan persatuan dan kesaatuan serta integrasi bangsa.

\section{Pembahasan}


Nilai-nilai budaya asli tentang persatuan dan kesatuan sebenarnya telah dimiliki dandijunjung tinggi oleh masing-masing suku bangsa di Indonesia. Kondisi seperti ini dibuktikan dengan keadaan yang damai, tenteram dan hubungan yang harmonis di antara sukubangsa pada masa lalu. Keadaanbaru berubah, ketika penjajah datang di bumi nusantara ini. Nilai-nilai kerukunan, persatuan dan kesatuan cenderung dikaburkan agar bangsa Indonesia terpecah belah, lemah dan mudah dijajah. Politik yang sangat terkenal yang digunakan penjajah adalah 'Politik De Vide et Impera'10. Akibatnya berbagai ajaran yang mengandung nilai-nilai persatuan dan kesatuan yang dimiliki oleh sukubangsa yang ada di Indonesia merupakan barang langka dan kurang dikenal oleh generasi muda khususnya dan masyarakat pada umumnya. Oleh karena itu nilai-nilai persatuan dan kesatuan perlu terus digali, dikembangkan, dan disosialisasikan agar integrasi nasional dapat diwujudkan. Adapun nilai-nilai itu antara lain:

1. Nilai yang terkait pada ajaran 'Desa mawa cara negara mawa tata' 11

Ajaran ini terdapat pada sukubangsa
Jawa yang mengandung petunjuk bagi kearifan pola hubungan antara suku bangsa maupun antar wilayah atau negara, dengan kesadaran bahwa orang dari daerah masing-masing mempunyai adat kebiasaan dan kebudayaan yang berbeda. Kesadaran akan adanya nilai yang berbeda tersebut menyebabkan setiap orang Jawa telah mempunyai pedoman dalam berinteraksi dengan orang di luar sukubangsa untuk tidak saling menyinggung perasaan atau saling menyakiti. Oleh sebab itu hubungan dibuat agar harmonis dengan melalui unggah-ungguh atau subasita atau tata krama dalam berhadapan dengan orang lain baik sesama sukubangsa, maupun antara atasan dengan bawahan atau orang tua dengan yang lebih muda. Semua itu diarahkan pada suasana selaras dan serasi yang digambarkan pada semboyan 'Leladi sesameng dumadi memayu hayuning sesami' yang berarti mengabdikan diri kepada masyarakat guna mencapai kebahagiaan sesama hidup.

2. Pada suku bangsa Bali terdapat sebuah ungkapan yang mengandung nilai persatuan yakni 'kiwa tengen mula matunggalan' (kiri kanan memang bersatu) 12 .

'Kiwa' dikiaskan dengan golongan lemah, dan dimaksudkan kaum wanita sedangkan kata 'tengen' adalah 
golongan kuat, maksudnya adalah kaum pria. Oleh karena itu untuk mencapai suatu hasil yang baik atau yang dicitacitakan maka kaum yang lemah dan kuat harus dipersatukan atau yang dicitacitakan maka kaum yang lemah dan kuat harus dipersatukan atau dapat bekerjasama. Dalam ungkapan tersebut terkandung nilai pentingnya persatuan antar kelompok mayoritas dan minoritas atau antar kelompok lemah dan kelompok kuat, meliputi antar sukubangsa, antar agama, kaya dan miskin dan lain sebagainya, agar dapat mencapai suatu kondisi yang ideal dalam masyarakat. Adanya nilai-nilai persatuan ini juga didasari akan pengetahuan bahwa setiap daerah itu mempunyai adat istiadat sendiri. Hal ini terdapat dalam ungkapan yakni 'len tongosno len suksesmanne'. Maksudnya adanya pengakuan terhadap budaya orang lain, sehingga menyebabkan masyarakat Bali cepat beradaptasi dengan orang lain, yang tidak satu suku ataupun satu paham demi integrasinya hubungan yang baik. Bervariasinya segala kekuatan yang ada didasari bahwa bila dipersatukan akan mendapatkan kekuatan yang tinggi guna pembangunan bangsa.

3. Nilai menjunjung persatuan dengan mengembangkan sikap toleransi.

Bangsa Indonesia yang terdiri dari banyak sukubangsa, dapat bersatu dalam satu wadah kesatuan berbangsa dan bernegara. Ini adalah berkat sikap dari masyarakat bangsa Indonesia sendiri yang menjunjung persatuan dan kesatuan. Kendatipun mereka berasal dari latar belakang sukubangsa yang memiliki kebudayaan berbeda-beda, akan tetapi mereka sepakat untuk bersatu membentuk bangsa yang besar yakni bangsa Indonesia. Keadaan ini menjadi ciri kepribadian bangsa Indonesia yang memberikan citra pada perwujudan kebudayaan Indonesia dengan budaya persatuannya.Nilainilai persatuan dan kesatuan ini ditunjang dengan mengembangkan sikap toleransi. Hal initelah dibuktikan dalam sejarah yakni dengan dikumandangkan-nya Sumpah Pemuda pada 28 Oktober 1928 yang mengikrarkan Satu Nusa, Satu Bangsa dan satu Bahasa, yaitu Indonesia.

4. Nilai menjunjung tinggi masyarakat dan kegotongroyongan.

Perbedaan-perbedaan pendapat adalah biasa, akan tetapi perbedaan pendapat itu bukan untuk dipertentangkan, melainkan untuk dicapai suatu kesepakatan. Itulah arti musyawarah yang sesuai dengan kepribadian bangsa. Dalam menghadapi masalah-masalah yang menyangkut kehidupan bersama, kita senantiasa menyelesaikan secara bersama-sama 
pula. Hal ini tercermin dalam ungkapan yang berbunyi 'berat sama dipikul ringan sama dijinjing'. Ungkapam ini mencerminkan nilainilai kegotong-royongan bangsa kita yang menjiwai persatuan dan kesatuan. Gotong royong dan musyawarah tidak mengenal keistimewaan atau pengecualian bagi orang besar, orang berpangkat maupun orang kaya.

\section{Nilai kesetiakawanan.}

Kesetiakawanan merupakan modal dasar dalam persatuan dan kesatuan. Kesetiakawanan yang dimaksud adalah kesetiakawanan antar sukubangsa, antar agama maupun antar kelompok atau golongan. Bagi masyarakat yang hidup dengan beraneka ragam sukubangsa, dan agama tindakan kesetiakawanan merupakan kunci bagi selaras dan serasinya hubungan. Kesetiakawanan perlu ditegakkan dalam rangka mewujudkan integrasi nasional. Untuk mencapai integrasi nasional kita harus mampu melepaskan diri dari kepentingan sukubangsa, agama, dan kelompok. Semboyan 'sepi ing pamrih rame ing gawe' yang berarti suka menolong dengan tidak menuntut balas harus kita laksanakan pada seluruh warga masyarakat di sekitar kita.

6. Nilai tenggang rasa.

Nilai tenggang rasa yang dimaksud adalah sikap menempatkan diri pada lingkungan sosial dan kesatuan sosial. Sikap ini sangat berguna pada masyarakat yang heterogen seperti Indonesia. Sikap tenggang rasa sangat diperlukan dalam kehidupan di masyarakat, karena adanya berbagai agama, sukubangsa dan latar belakang budaya di Indonesia. Dengan sikap tenggang rasa tersebut segala kehidupan bermasyarakat dijamin dapat selaras dan serasi. Perwujudan sikap tenggang rasa dalam kehidupan masyarakat dengan budaya yang beragam akan sangat membentuk keharmonisan. Perwujudan sikap tenggang rasa tersebut seperti menahan diri, menghormati pendapat orang lain dan sebagainya. Dengan kata lain segala tindakan kita harus berorientasi pada orang di sekitar kita dan tidak mementingkan diri kita sendiri. Dalam ungkapan Jawa yang berbunyi 'aja njiwit nek ora gelem dijiwit' yang berarti jangan mencubit kalau tidak ingin dicubit. Nilai yang terkandung di dalamnya adalah menjaga keselarasan sosial dengan tidak mendahului membuat keributan dengan orang di sekitar kita. Nilai tenggang rasa ini merupakan sarana bagi persatuan dan kesatuan bangsa serta integrasi nasional.

\section{Kesimpulan}

Negara Indonesia yang terdiri dari beribu-ribu pulau besar dan kecil, dan dihuni beratus-ratus sukubangsa diikat 
oleh satu semboyan yang mampu mempersatukan bangsa. Semboyan itu tidak lain adalah 'BHINNEKA TUNGGAL IKA'. Memantapkan persatuan dan kesatuan bangsa serta mempertahankan integrasi nasional merupakan agenda yang tidak kunjung usai, dalam bentangan waktu yang panjang. Komitmen dan perjuangan untuk membangun Indonesia yang merdeka bersatu berdaulat, adil dan makmur bukan hanya menjadi tugas generasi sekarang, tetapi jauh hari telah dilakukan oleh generasi-generasi terdahulu, dan selanjutnya menjadi tugas generasi-generasi yang akan datang. Kita percaya bahwa tiada hasil karya dan warisan nilai yang lebih indah dan membahagiakan jika kelak di kemudian hari Indonesia benar-benar menjadi bangsa dan negara yang besar dan maju, di atas lahan nilai dan jati diri kebangsaannya. Marilah kita semua menjadi bagian dan upaya besar bangsa Indonesia untuk membangun keutuhan negerinya, melawan berbagai kekuatan yang hendak memecah belah persatuan dan kesatuan bangsa yang didambakan bersama. Akhirnya dalam kesempatan ini pula akan kami kutibkan pemikiran Jenderal Wiranto ${ }^{13}$ tentang 'lima langkah strategis' yang dapat memper- kukuh persatuan dan kesatuan, sebagai berikut:

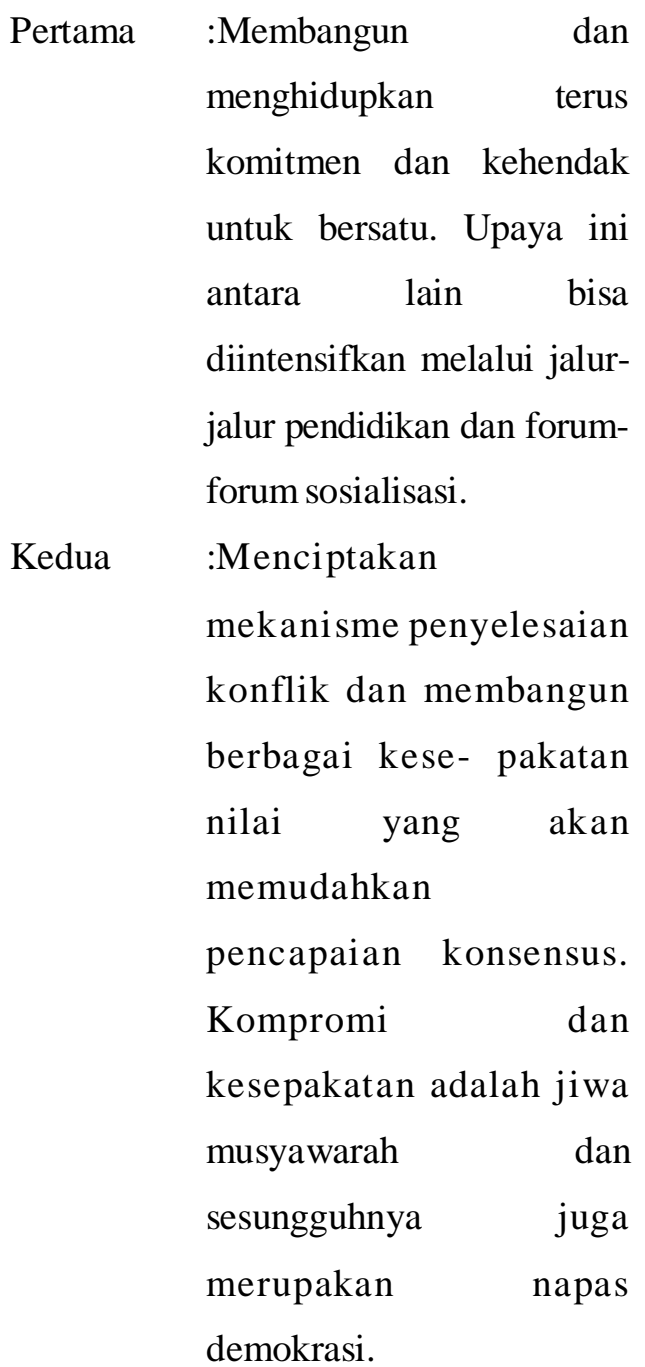

Ketiga :Membangun

kelembagaan (pranata) yang berakarkan pada nilai dan norma yang menyubur- kan persatuan dan kesatuan bangsa secara struktural dan kultural.

Keempat : Merumuskan kebijakan dan regulasi yang konkrit, tegas dan tepat dalam 
segala aspek kehidupan dan pembangunanbangsa, yang menjamin terwujudnya keadilan bagi semua wilayah dan kelompok-kelompok masyarakat.

Kelima :Pengembangan karakter dan perilaku kepemimpinan pada semua level interaksi dan bidang kehidupan yang mengedepankan kearifan, keterbukaan, sensitif terhadap aspirasi masyarakat dan responsif terhadap segala permasalahan yang dihadapi.

Semoga dengan dilandasi persatuan dan kesatuan yang kokoh, Negara Kesatuan Republik Indonesia tetap jaya, eksis dan lestari sepanjang masa. Amin.

\section{Daftar Pustaka}

Sodik, M. A., Suprapto, S. I., \& Pangesti, D. (2013). Faktor-Faktor Yang Berhubungan Dengan Pelaksanaan Pelayanan Prima Pegawai Di Rsui Orpeha Tulungagung. STRADA Jurnal Ilmiah Kesehatan, 2(1), 24-32.
Siyoto, S., \& Sodik, M. A. (2015). Dasar metodologi penelitian. Literasi Media Publishing.

Attoriq, S., \& Sodik, M. A. (2018). Pencegahan Dan Pengendalian Infeksi Terkait Pelayanan Kesehatan Di Lahan Praktik.

Sodik, M. A. (2018). Merokok \& Bahayanya.

Setyani, A. T., \& Sodik, M. A. (2018). Pengaruh Merokok Bagi Remaja Terhadap Perilaku dan Pergaulan Sehari-hari.

Oktoriani, E. N., Sutrisno, J., Mayasari, E., \& Sodik, M. A. (2018). Analysis of medical record complete flexibility to complete claims of health BPJS RS Baptis Kota Batu. Journal of Global Research in Public Health, 3(1), 46-53.

Soekarno, S. (1990). Hak dan kewajiban 
